DOI: $10.31866 / 2410-1915.21 .2020 .208262$

UDC 792.82:7.072.3]:050(477.54-25)"1925/1928"

\title{
BALLET CRITICISM ON THE PAGES OF THE NEW ART MAGAZINE (KHARKIV, 1925-1928)
}

\section{Alina Pidlypska}

PhD in Art Studies, Professor, ORCID: 0000-0002-7892-337X, alinaknukim@ukr.net, Kyiv National University of Culture and Arts, 36, Ye. Konovaltsia St., Kyiv, 01133, Ukraine

\section{For citations:}

Pidlypska, A. (2020). Ballet Criticism on the Pages of the New Art Magazine (Kharkiv, 1925-1928). Culture and Arts in the Modern World, 21, 241-250. https://doi.org/10.31866/2410-1915.21.2020.208262.

The purpose of the article is to analyse and typologize the ballet criticism of the magazine New art (Kharkiv, 1925-1928). To achieve this goal, a number of principles and methods were used: the historical approach and analytical method make possible to analyse scientific and critical articles in the chronological order, the comparative method to compare articles separating common and distinct ideas and concepts; the typological method - to classify critical publications on ballet topics. The scientific novelty of the article is that the content of the magazine New Art (Kharkiv, 1925-1928) was analysed through the prism of ballet criticism for the first time. Conclusions. In the conditions of the gradual departure from the ideas of the proletarian culture of the early 1920s in the USSR, with a complete rejection of the academic traditions of classical ballet, in the middle of 1920s there was a turn to a certain independence of the Ukrainian culture, Ukrainianlanguage magazines appeared, including the theatrical weekly New art, the content of which included the ballet criticism. The magazine reflects some aspects of the emergence of theatre studies (within which ballet studies developed) in Ukraine, which went parallel with the formation of ballet criticism. Rather conditionally, the content of publications of the New art related to ballet criticism can be divided into groups: theatrical theoretical and methodological (Ya. Mamontov and others); on the theoretical aspects of theatre, in particular, ballet criticism (I. Turkeltaub, K. Rafalskyi, M. Khrystovyi); ballet reviews, interviews, reviews, reports, chronicles (Yu. Zhihela, P. Kozytskyi, F. Malkov, H. Neivi). The New art conceptualized requirements for theatrical, including ballet, criticism: social (orientation to the ruling class of the proletariat), ideological and axiological (the transition from the propaganda of revolutionary and abstract, agitational to ideological and artistic values), anthropological (the formation of a physically and mentally new person). The two groups can be distinguished among the ballet reviews: the first - non-ideological publications, mainly applying an aesthetic and artistic approach to reviewing; the second group consists of those who condemn experimentation (constructive, body-plastic, etc.), focusing on the formation of mono-ideological approaches.

Keywords: ballet criticism; the New Art magazine; ballet; choreography; dance. 


\section{Introduction}

Among the specialized art publications of the 1920s in Ukraine an important place is occupied by the weekly magazine New art, which was published in Kharkiv in 1925-1928 and covered the issues of music, visual, and film art, as well as the key questions of the theatre development, in particular ballet theatre. Ballet criticism in the New art has become a significant component of the ballet discourse that was in the process of its creation in Ukraine. The study of critical articles is important in terms of recreating a holistic panorama of ballet art and its reflections.

T. Koval (1998) and O. Orlyk (2009) pay attention to the New art as a notable periodical chronicle of the 1920s in the context of a study of the Ukrainian magazines. The article by Yu. Poliakova (2011) is devoted to the analysis of the content of the New art, and on the basis of magazine's publications, the author also reviewed the theatrical discussion between Ya. Mamontov and L. Kurbas (Poliakova, 2019). O. Halonska (2011) relies on publications in the New Art to recreate the ways of the Ukrainian musical comedy's formation. I. Lobanova (2011) uses magazine's publications to demonstrate the way how the creative work of the stenographers-constructivists of the State Ukrainian Opera theatre was rated in Kharkiv press. V. Sobiianskyi's $(2010 ; 2011)$ approach was the closest to the issue of critical discourse of the ballet theatre in the New art, but did not focus on it, having considered the theatre and critical publications of the weekly magazine. The materials of the magazine are used in the process of reviewing the repertoire of the ballet theatre of the Soviet Ukraine in the second half of the $20^{\text {th }}$ century (Pidlypska, 2020) and the activities of K. Holeizovskyi in Ukraine (Pidlypska, 2019). A comprehensive study on the critical discourse of ballet theatre on the pages of the New art has not yet been carried out.

\section{Purpose of the article}

The purpose of the article is to analyse and typologize the ballet criticism of the magazine New art (Kharkiv, 1925-1928).

To achieve this goal, a number of principles and methods were used: the historical approach and analytical method make possible to analyse scientific and critical articles in the chronological order, the comparative method - to compare articles to identify common and distinct ideas and concepts; the typological method - to classify critical publications on ballet topics.

\section{Main research material}

According to the typology of theatrical and artistic periodicals of the 1920s in Ukraine, proposed by V. Sobiianskyi (2010), the magazine New art can be attributed to the "thick" magazines, which are characterized by "a high theoretical level of art evaluation, therefore, the internal structure of these magazines has already been established in the form of permanent sections" (p. 202). Yu. Poliakova (2011), introducing its own classification of the theatrical peri- 
odicals, assigns magazines by subject: scientific, theatrical and practical, mass, and classifies the New art as the scientific one, which is, in our opinion, rather subjective. The author warns that "in its purest form, such publications have not been found" (p. 112), and the scientific magazines may contain advertising information (each issue of the New art printed theatre repertoire, information about performances, concerts, and so on).

The magazine is created in the context of the policy of ukrainization, the use of the Ukrainian language in the periodicals, changes in emphasis - shifting attention to the Ukrainian issues, which has a positive impact on the development of domestic theatre studies, including ballet criticism.

A number of publications in the New art are devoted to the theatre studies methodology, which directly affects the critical activity. Theatre art in the new socio-cultural realities, according to the famous theatre critic Ya. Mamontov in 1926, does not have its own well-established forms, generally recognized methods, scientific definition and classification of the theatrical trends. In his detailed presentation "Modern theatre in its main directions", Mamontov analyses the work of the Russian theatre specialists P. Markov (presented the classification of theatre directions according to the system of artistic means, namely: psychological, aesthetic, revolutionary theatre) (Mamontov, 1926a) and A. Redko (presented the classification according to the philosophical basis of the theatrical trends: realistic, relative, "compromise forms") (Mamontov, 1926b), accusing them of the lack of a sociological approach. In the final part of the article, the author insists on the different ways of development of the Russian and Ukrainian theatres, which is an important methodological basis of the domestic theatre studies (Mamontov, 1926c). Among the publications of Ya. Mamontov, an article, which reflects the theoretical and methodological search of the Ukrainian theatre studies in the late 1920s, in particular, the formation of the conceptual and categorical apparatus in the situation of the penetration of the realistic trends, became notable. The theatre critics proposed the term "constructive realism", which could become an adequate definition for the search for the renewal of art in all types of theatre, including ballet, since constructivism, which is characterized by conventionality, generalization, is inherent in the art of choreography (Mamontov, 1927). But later, the central authorities made a choice in favour of socialist realism, which prevailed from the 1930 s to the 1980 s.

In the middle and the second half of the 1920s there were lively debates on the methodological foundations of theatre criticism including ballet, opera, operetta, etc. In one of the first issues of the New art, the famous theatre critic I. Turkeltaub (1925) called for the creation of the special institution (Institute of Art Studies), such as one in Moscow ("Russian Academy of Artistic Sciences") and in Leningrad ("Institute of Art History"), in order to develop a scientific basis for the artistic activity, "to begin an organised study of art issues and phenomena of artistic life in Ukraine".

K. Rafalskyi (1925) tried to formulate the main methodological principles of theatre critics, speaking about the social determinants in the evaluation activities of critics (the importance of the class approach, because works express 
the ideology and are designed for a specific class, and in the USSR for the "winning class" - proletariat), as well as ideological and axiological concepts (transition from the propaganda of the revolutionary and abstract, agitational to the ideological and artistic values and the increase of actually artistic requirements to the works). Concern about the lack of methods, principles, directions of criticism is expressed in the article "Again and again about the same thing", the attention is focused on the need to combat "bourgeois" manifestations (individualism, aestheticism) and to apply the criteria of idealism, class system (criticism must broadcast the "class ideology of the proletariat"), and social value ("Znovu y znovu pro te same", 1926).

M. Khrystovyi positions theatre criticism as a socially necessary factor in the overall construction of the socialist culture, recognizes the low artistic level of the audience and insufficient ideologization of the repertoire, focuses on the anthropological moment (the proletariat is called "the new organizer of the social life"). The author expresses the opinion that the task of criticism is to identify the ideological and social value of the performances, condemns the fascination exclusively with aesthetics, and is concerned with educating the audience through "Marxist criticism" (Khrystovyi, 1926a).

Let's proceed to the consideration of the critical ballet publications. Reviews on ballet performances can be divided into two groups - none-ideological and with elements of translation of certain ideological attitudes.

The following articles belong to the first group: the article "Swan Lake" ("Lebedyne ozero", 1925), which traditionally highlights the work of the choreographer, artist, soloists, conductor; "To the ballet "Le Corsaire" (B, 1926) in Kharkiv, where attention is drawn to the constructivist characteristics in the performances ("flying ballet", "movement plane"); review on E. Lopukhova's performance (Zhihela, 1926b). In his review, which is also devoid of ideological features, on the ballet "Le Corsaire" staged by M. Moiseiev, I. Turkeltaub (1926) emphasises the modern approach to the realisation of the performance, the absence of a "conservative stencil". A surprisingly approving review was published on "Swan lake" at the capital's State Opera, where only artistic merits and demerits of the performance were discussed (Nevermore, 1928b).

Mainly the musicological aspects of S. Prokofiev's ballet “The Tale of a Jester Who Cheated Seven Other Jesters" were highlighted in the review by F. Malkov, who considers ballet as a significant step towards modernization and departure from the main ballet performances of the past (Malkov, 1928). The critics were fascinated by the game of the architectural forms in the ballet "Joseph the Beautiful" (composer S. Vasylenko) by choreographer K. Holeizovskyi, realizing that his work is aimed not only at destroying traditions, but mainly at experimenting in the direction of finding a new choreographic language (Kozytskyi, 1928).

The second group of ballet reviews, where certain signs of the totalitarian ideology are conceptualized, includes a review on the ballets "Scheherazade" and "Spanish Capriccio", staged by ballet master Boiko at the Theatre of Musical Comedy in 1926. Yu. Zhihela (1926c) named the perfor- 
mance "amateur" that "is flavoured with unhealthy bias", a conglomerate of "amateurism and inability", asserts the right of "new audience" - a worker on "healthy performance". There are aesthetic, social and anthropological ("new man") accents.

$\mathrm{H}$. Neivi (1927) is outraged by the conservatism of the ballet repertoire that in Ukraine for ten years has not departed from the reproduction of multi-act classical ballets, condemns the loyalty to old traditions and is dismissive of the ballet "Don Quixote", which opened the Kharkiv Opera theatre season (1927). The success of the ballet on the modern theme of R. Gliere's "The Red Poppy" choreographed by V. Tikhomirov and L. Lashchilin on the stage of the Bolshoi theatre in Moscow, despite the compromise solution (realisation of the modern theme by means of the classical dance) contributed to the fact that it became a kind of a reference point for the modern ballet repertoire.

And a few weeks later, M. Moiseiev on the pages of the New art told about the active work on "The Red Poppy", where the emphasis is on the mass scenes, as the main means of communicating the "class and social" essence of the work ("Do postanovky baleta", 1927). After the premiere the reviewers welcomed the choreographer's findings, decoration of Petrytskyi, successful performance accomplishments, and the creative work of the conductor, but made a number of comments: the authors of the libretto and choreographer were accused of lacking the emphasis on the class aspect, because the main character remained pure ballet figure, the Chinese proletariat has not played a proper role throughout the play, only at the end; the Soviet sailors behaved too passively; in general, the plot was built on clichés of pre-revolutionary ballets using pure forms of classical dance (the scene of sleeping) (Nevermore, 1928a). Thus, the class and ideological requirements in the review prevailed over the artistic and aesthetic ones, which was a sign of the times.

The New art magazine also published reviews on touring performances, in fact, variety performances: for example, a paragraph by Yu. Zhihela (1926a) about the tours of famous artists L. Zhukov and M. Reizen in Kharkiv and Viktorina Kriger in Kyiv (Yu. Zh, 1926), etc.

We should also mention small reports and news items: for example, as an announcement a few lines about the future performance of the ballet "Corsair" by M. Moiseiev in Kharkiv (Khrystovyi, 1926c); an announcement of performances by E. Lopukhova (Khrystovyi, 1926b); a small note about the Russian artists of S. Diaghilev's show (Zet, 1926), etc.

This article does not cover all aspects of the study of ballet criticism in the New art magazine (Kharkiv, 1925-1928), among the promising directions are identifying the affiliation of ballet critics to various aesthetic and philosophical schools, clarifying the place of ballet critics of the New art in the context of critical publications on ballet themes in the periodicals of the second half of the 1920s in Ukraine and the USSR, etc.

The significance of the article lies in the possibility of using its materials and results for further research of ballet criticism and choreographic art in general while teaching the theoretical choreographic disciplines in higher education institutions of relevant fields. 


\section{Conclusions}

In the conditions of the gradual departure from the ideas of the proletarian culture of the early 1920s in the USSR, with a complete rejection of the academic traditions of classical ballet, in the middle of 1920s there was a turn to a certain independence of the Ukrainian culture, Ukrainian-language magazines appeared, including the theatrical weekly New art, the content of which included the ballet criticism. The magazine reflects some aspects of the emergence of theatre studies (within which ballet studies developed) in Ukraine, which went parallel with the formation of ballet criticism.

Rather conditionally, the content of publications of the New art related to ballet criticism can be divided into groups: theatrical theoretical and methodological (Ya. Mamontov and others); on the theoretical aspects of theatre, in particular, ballet criticism (I. Turkeltaub, K. Rafalskyi, M. Khrystovyi); ballet reviews, interviews, reports, chronicles (Yu. Zhihela, P. Kozytskyi, F. Malkov, H. Neivi).

In the New art conceptualized requirements for theatrical, including ballet, criticism: social (orientation to the ruling class of the proletariat), ideological and axiological (the transition from the propaganda of revolutionary and abstract, agitational to ideological and artistic values), anthropological (the formation of a physically and mentally new person).

The two groups can be distinguished among the ballet reviews: the first non-ideological publications, mainly applying an aesthetic and artistic approach to reviewing; the second group consists of those who condemn experimentation (constructive, body-plastic, etc.), focusing on the formation of mono-ideological approaches.

In general, the New art played a significant role in shaping the critical discourse of ballet art in Ukraine in 1925-1928.

\section{References}

B. (1926). Do postanovky baleta "Korsar" [To the staging of the ballet "Le Corsaire"]. Nove mystetstvo, 7,3 [in Ukrainian].

Do postanovky baleta "Chervonyi mak" v Kharkivskii derzhavnii operi. Rozmova z postanovshchykom M. Moiseievym [To the staging of the ballet "The Red Poppy" at the Kharkiv State Opera. Conversation with director M. Moiseiev]. (1927). Nove mystetstvo, 27, 5 [in Ukrainian].

Halonska, O. I. (2011). Rezhyser Yanuarii Bortnyk ta shliakhy stanovlennia ukrainskoi muzychnoi komedii [Director Yanuarii Bortnyk and ways of formation of Ukrainian musical comedy]. The Scientific Issues of Ternopil National Pedagogical Volodymyr Hnatiuk University. Specialization: Art Studies, 2, 154-158 [in Ukrainian].

Khrystovyi, M. (1926a). Pro nashu teatralnu krytyku [About our theatrical criticism]. Nove mystetstvo, 25, 1-2 [in Ukrainian].

Khrystovyi, M. (1926b). Khronika. Kyiv. Khoreohrafichni vechory Lopukhovoi [Chronicle. Kyiv. Choreographic evenings of Lopukhova]. Nove mystetstvo, 8, 11-12 [in Ukrainian]. 
Khrystovyi, M. (1926c). Khronika. Kharkiv. Derzhavna opera [Chronicle. Kharkiv. State Opera]. Nove mystetstvo, 4, 11-13 [in Ukrainian].

Koval, T. V. (1998). Zhurnaly Ukrainy 1917-1928 rokiv u fondi Natsionalnoi biblioteky Ukrainy imeni V.I. Vernadskoho yak istoryko-knyhoznavche dzherelo [Journals of Ukraine of 1917-1928 in the fund of the National Library of Ukraine named after Vernadsky as a historical and bibliographical source]. (Abstract of PhD Dissertation). National Library of Ukraine named after V. I. Vernadsky, Kyiv [in Ukrainian].

Kozytskyi, P. (1928). Druha polovyna sezonu v Stolychnii operi [The second half of the season at the Metropolitan Opera]. Nove mystetstvo, 14-15, 4 [in Ukrainian].

Lebedyne ozero [Swan Lake]. (1925). Nove mystetstvo, 2, 4 [in Ukrainian].

Lobanova,I.V.(2011).Vid apolohii avanhardu do apolohii realizmu: tvorchist stsenohrafivkonstruktyvistiv Derzhavnoho ukrainskoho opernoho teatru v otsintsi kharkivskoi presy (1925-1934) [From the apology of the avant-garde to the apology of realism: the work of scenographers-constructivists of the State Ukrainian Opera Theatre in the assessment of the Kharkiv press (1925-1934)]. The Journal of V. N. Karazin Kharkiv National University. Series: Social Communications, 3(968), 68-73 [in Ukrainian].

Malkov, F. (1928). "Kazka pro blaznia, shcho simokh blazniv peremudryv" ["The tale of a jester who cheated seven other jesters"]. Nove mystetstvo, 8,7 [in Ukrainian].

Mamontov, Ya. (1926a). Suchasnyi teatr v yoho osnovnykh napriamkakh [Modern theatre in its main areas]. Nove mystetstvo, 14, 4-6 [in Ukrainian].

Mamontov, Ya. (1926b). Suchasnyi teatr v yoho osnovnykh napriamkakh (prodovzhennia) [Modern theatre in its main areas (continued)]. Nove mystetstvo, 15, 4-6 [in Ukrainian].

Mamontov, Ya. (1926c). Suchasnyi teatr v yoho osnovnykh napriamkakh (zavershennia) [Modern theatre in its main directions (completion)]. Nove mystetstvo, 18, 4-6 [in Ukrainian].

Mamontov, Ya. (1927). Teatralnyi front pered Zhovtnevym desiatyrichchiam [Theatrical front before the October Decade]. Nove mystetstvo, 22, 2-3 [in Ukrainian].

Neivi, H. (1927). "Don Kikhot". Baletnyi spektakl v Derzhavoperi ["Don Quixote". Ballet performance at the State Opera]. Nove mystetstvo, 19, 13 [in Ukrainian].

Nevermore. (1928a). Balet "Chervonyi Mak" v Kharkivskii Derzhavnii Operi [Ballet "Red Poppy" at the Kharkiv State Opera]. Nove mystetstvo, 1, 6-7 [in Ukrainian].

Nevermore. (1928b). "Lebedyne ozero" v Stolychnii Derzhavnii Operi ["Swan Lake" at the Metropolitan State Opera]. Nove mystetstvo, 1, 6-7 [in Ukrainian].

Orlyk, O. (2009). Zhurnalni vydannia 20-30-kh rokiv XX stolittia yak dzherelo doslidzhennia vydavnychoi spravy v Ukraini [Magazines of the 20s and 30s of the $20^{\text {th }}$ century as a source of research in Ukraine]. Bulletin of the Book Chamber, 6, 37-40 [in Ukrainian].

Pidlypska, A. (2019). Balety Kasiana Holeizovskoho "Iosyp Prekrasnyi" ta "Hrotesk" v Radianskii Ukraini druhoi polovyny 20-kh rokiv XX stolittia: krytychnyi dyskurs [Kasian Holeizovskyi 's ballets "Joseph the Beautiful" and "Grotesque" in the Soviet Ukraine in the second half of the 1920s: a critical discourse]. Dance studies, 2(2), 158-167. https://doi.org/10.31866/2616-7646.2.2.2019.188816 [in Ukrainian].

Pidlypska, A. (2020). Repertuar baletnoho teatru Radianskoi Ukrainy druhoi polovyny 20-kh rokiv XX stolittia u svitli krytyky [The repertoire of the ballet theatre of the Soviet Ukraine in the second half of the 1920s in the light of criticism]. National 
Academy of Managerial Staff of Culture and Arts Herald, 1, 94-98. https://doi. org/10.32461/2226-3209.1.2020.196573 [in Ukrainian].

Poliakova, Yu. Yu. (2011). Teatralnaia periodika Kharkova (1917-1933): tipologiia, tematika, problematika [Theatrical periodicals of Kharkiv (1917-1933): typology, themes, problems]. Odesa National University Herald. Library studies, Bibliography studies, Bibliology, 16(1-2), 110-126 [in Russian].

Poliakova, Yu. Yu. (2019). Teatralna dyskusiia yak hra (Iakiv Mamontov i Les Kurbas) [Theatrical discussion as a game (Iakiv Mamontov and Les Kurbas)]. Visnyk of V. N. Karazin Kharkiv National University. Series: Philology, 81, 99-104 [in Ukrainian]. Rafalskyi, K. (1925). Krytyka [Critics]. Nove mystetstvo, 7, 1 [in Ukrainian].

Sobiianskyi, V. (2010). Typolohiia teatralno-mystetskykh periodychnykh vydan Ukrainy 1920-kh rokiv [Typology of theatrical and artistic periodicals of Ukraine in the 1920s]. Naukovyi visnyk Kyivskoho natsionalnoho universytetu teatru, kino i telebachennia imeni I. K. Karpenka-Karoho, 7, 196-215 [in Ukrainian].

Sobiianskyi, V. (2011). Teatralno-krytychni publikatsii na storinkakh kharkivskoho tyzhnevyka "Nove mystetstvo" (1925-1928) [Theatrical-critical publications on the pages of the Kharkiv weekly "New Art" (1925-1928)]. Notes of the Shevchenko Society. Proceedings of the Theatre Studies Commission, 262, 236-253 [in Ukrainian]. Turkeltaub, I. (1925). Naukove vyvchennia mystetstva [Scientific study of art]. Nove mystetstvo, 5, 2 [in Ukrainian].

Turkeltaub, I. (1926). "Korsar" ["Corsair"]. Nove mystetstvo, 10, 7 [in Ukrainian].

Yu. Zh. (1926). Viktorina Kriher. Nove mystetstvo, 16, 10 [in Ukrainian].

Zet. (1926). Ruski baletni artysty u Nimechchyni [Russian ballet dancers in Germany]. Nove mystetstvo, 5, 5 [in Ukrainian].

Zhihela, Yu. (1926a). Balet M. Reizen i L. Zhukova [Ballet by M. Reisen and L. Zhukov]. Nove mystetstvo, 3, 7 [in Ukrainian].

Zhihela, Yu. (1926b). Kontsert z E. Lopukhovoiu [Concert with E. Lopukhova]. Nove mystetstvo, 9, 8 [in Ukrainian].

Zhihela, Yu. (1926c). "Shekherezada" y "Ispanske kaprychio" ["Scheherazade" and "Spanish Capriccio"]. Nove mystetstvo, 8, 9 [in Ukrainian].

Znovu y znovu pro te same [Again and again about the same thing]. (1926). Nove mystetstvo, 7, 1 [in Ukrainian]. 


\section{БАЛЕТНА КРИТИКА НА СТОРІНКАХ ЖУРНАЛУ «НОВЕ МИСТЕЦТВО» (ХАРКІВ, 1925-1928)}

\section{Підлипська Аліна Миколаївна}

Кандидат мистеццтвознавства, професор, ORCID:0000-0002-7892-337X, alinaknukim@ukr.net, Київський національний університет культури і мистецтв, Київ, Україна

Мета статті - проаналізувати і типологізувати балетну критику журналу «Нове мистецтво» (Харків, 1925-1928). Для досягнення мети було використано ряд принципів і методів: історичний підхід та аналітичний метод дозволили проаналізувати наукові і критичні статті у хронології, порівняльний метод - зіставити статті задля виокремлення спільних та відмінних ідей, концепцій; типологічний класифікувати критичні публікації балетної тематики. Наукова новизна полягає в тому, що вперше було проаналізовано контент журналу «Нове мистецтво» (Харків, 1925-1928) крізь призму балетної критики. Висновки. В умовах поступового відходу від ідей Пролеткульту початку 20-х рр. ХХ ст. в СРСР, із повним запереченням академічних традицій класичного балету, в середині 1920-х рр. відбувся поворот до певної самостійності української культури, з'явилися україномовні часописи, серед яких театрознавчий щотижневик «Нове мистецтво», до контенту якого входила балетна критика. У журналі віддзеркалено деякі аспекти постання театрознавства (в межах якого розвивалося балетознавство) в Україні, що йшло паралельно зі становленням балетної критики. Досить умовно контент публікацій «Нового мистецтва», пов'язаних із балетною критикою, можна розділити за групами: театрознавчий теоретико-методологічний (Я. Мамонтов та ін.); із теоретичних аспектів театральної, зокрема балетної критики (І. Туркельтауб, К. Рафальський, М. Христовий); балетні рецензії, інтерв’ю, відгуки, повідомлення, хроніки (Ю. Жігела, П. Козицький, Ф. Малков, Г. Нейві). У «Новому мистецтві» концептуалізовано вимоги до театральної, зокрема й балетної, критики: соціальні (орієнтація на панівний клас пролетаріату), ідеологічні та аксіологічні (перехід від пропагування революційноабстрактних, агітаційних до ідеологічно-художніх цінностей), антропологічні (формування фізично, психічно, ментально нової людини). Серед балетних рецензій можна виокремити дві групи: перша - позаідеологічні публікації, що переважно застосовують естетико-художній підхід до рецензування; друга - ті, що засуджують експериментування (конструктивні, тілесно-пластичні та ін.), зорієнтовані на формування моноідеологічних підходів.

Ключові слова: балетна критика; журнал «Нове мистецтво»; балет; хореографія, танець. 


\title{
БАЛЕТНАЯ КРИТИКА НА СТРАНИЦАХ ЖУРНАЛА «НОВОЕ ИСКУССТВО» (ХАРЬКОВ, 1925-1928)
}

\author{
Пидлыпская Алина Николаевна,
}

Кандидат искусствоведения, профессор, ORCID:0000-0002-7892-337X, alinaknukim@ukr.net, Киевский национальный университет культуры и искусств, Киев, Украина

Цель статьи - проанализировать и типологизировать балетную критику журнала «Новое искусство» (Харьков, 1925-1928). Для достижения цели были использованы ряд принципов и методов: исторический подход и аналитический метод позволили проанализировать научные и критические статьи в хронологической последовательности, сравнительный метод - сопоставить статьи для выделения общих и отличительных идей, концепций; типологический - классифицировать критические публикации балетной тематики. Научная новизна заключается в том, что впервые был проанализирован контент журнала «Новое искусство» (Харьков, 1925-1928) сквозь призму балетной критики. Выводы. В условиях постепенного отхода от идей Пролеткульта начала 20-х гг. XX в. в СССР, с полным отрицанием академических традиций классического балета, в середине 1920-х гг.произошел поворот копределенной самостоятельности украинской культуры, появились русскоязычные журналы, среди которых театроведческий еженедельник «Новое искусство», в контент которого входила балетная критика. В журнале отражены некоторые аспекты формирования театроведения (в рамках которого развивалось балетоведение) в Украине, которое шло параллельно со становлением балетной критики. Достаточно условно контент публикаций «Нового искусства», связанных с балетной критикой, можно разделить на группы: театроведческий теоретико-методологический (Я. Мамонтов и др.), по теоретическим аспектам театральной, в частности, балетной критики (И. Туркельтауб, К. Рафальский, М. Христов), балетные рецензии, интервью, отзывы, сообщения, хроники (Ю. Жигела, П. Козицкий, Ф. Малков, Г. Нейви). В «Новом искусстве» концептуализированы требования к театральной, в том числе и балетной, критике: социальные (ориентация на господствующий класс пролетариата), идеологические и аксиологические (переход от пропаганды революционно-абстрактных, агитационных к идеологически-художественным ценностям), антропологические (формирование физически, психически, ментально нового человека). Среди балетных рецензий можно выделить две группы: первая - внеидеологические публикации, преимущественно применяют эстетико-художественный подход $\mathrm{k}$ рецензированию; вторая осуждающие экспериментирования (конструктивные, телесно-пластические и др.), ориентированные на формирование моно идеологических подходов.

Ключевые слова: балетная критика; журнал «Новое искусство»; балет; хореография; танец. 